\title{
Geographic Information System for Detecting Spatial Connectivity Brown Planthopper Endemic Areas Using a Combination of Triple Exponential Smoothing - Getis Ord
}

\author{
Sri Yulianto J. P. ${ }^{1}$, Nugraheni Widyawati ${ }^{2}$, Kristoko D. H. ${ }^{1}$ \& Bistok Hasiholan S. ${ }^{2}$ \\ ${ }^{1}$ Faculty of Information Technology, Satya Wacana Christian University, Salatiga, Indonesia \\ ${ }^{2}$ Faculty of Agriculture Satya Wacana Christian University, Salatiga, Indonesia \\ Correspondence: Sri Yulianto J.P, Faculty of Information Technology, Satya Wacana Christian University, \\ Salatiga, Indonesia. E-mail: sri.yulianto@staff.uksw.edu
}

Received: June 9, 2014

doi:10.5539/cis.v7n4p21
Accepted: June 17, $2014 \quad$ Online Published: August 19, 2014

URL: http://dx.doi.org/10.5539/cis.v7n4p21

\begin{abstract}
This study aims to develop a GIS application to detect the possible formation of brown planthoppers (BPH) (Nilaparvata lugens.Stal) endemic areas based on spatial trend, hierarchical effects and risks areas caused of spatial connectivity in a particular area. The study was conducted through five stages: (1) the collection and preprocessing of research data, (2) database development, (3) the creation of the component class Exponential Smoothing, Weight Metrics and Getis Ord, (4) development of a Early Warning class and GIS applications, and (5) information visualization in the form of graphs, maps and tables. The results show that the software component in this study; the class prediction engine; Getis Ord class and class early detection function optimally generate predictive, endemic regions and early warning information on the period ahead.
\end{abstract}

Keywords: spatial connectivity, early warning, triple exponential smoothing, Getis Ord

\section{Introduction}

Geographic Information Systems (GIS) began to develop in the early 1960s as a result of scientific research that was collaborated with Science Geography Cartography, Computer Sciences and Remote Sensing Science (Ji \& Cui, 2011). GIS according to Taupier and Willis (1994) is a set of tools and methods to collect, store, manage, convert, analyze, summarize and display spatial data in order to comprehend and look for the solution of the real world problems.

GIS is applied for several purposes: (1) analyzing temporary data changes, (2) determining spatial characteristics, such as proximity, contiguity, patch size and form, (3) generating visualization, model or simulation to generate new spatial data (Johnson, 1990). Architecturally SIG is composed of four major components, (1) data model , (2) storage, (3) analyzing method, and (4) representing geographic information (Anselin, 1993a;Anselin, 1993b; Anselin, 1994; Anselin , 1995; Anselin, 1996; Anselin, 1998).

The GIS analyzing method is determined based on GIS application development purposes. The focus of this research is to develop GIS applications to detect possible formation of BPH endemic areas based on spatial trend, hierarchical effects and risks areas caused of spatial connectivity in a region (Langford, 1999). Connectivity between complex spatial objects in an ecosystem will form a complex spatial pattern and structure factors involving topography, climate, anthropogenic and biotic interactions (Wang et al., 2009; Win et al., 2011; Bottrell, 2012; Rudnick, 2012; Theobald, 1999). Measurement of the degree of spatial connectivity is done by using the method of Spatial Autocorrelation (Chowell et al., 2006; Chen \& Jiang, 2010). Spatial Autocorrelation method $\mathrm{Gi}^{*}$ particular technique can yield information migration patterns and population distribution of BPH in the surrounding area by looking at the spatial structure. Connectivity between the periods of attack BPH can be measured using the approach of time - series; this study used the Triple Exponential Smoothing method. This method was chosen with the assumption that the wave of attacks BPH occurs following the trends and seasonal patterns.

$\mathrm{BPH}$ is one pest of rice crops in tropical and sub- tropical regions of Asia which has the ability to migrate long distances, following the Monsoon. BPH pest infestation first occurred in 1931, destroying most of the rice plant 
in Bogor, Mojokerto in 1939 and in Yogyakarta in 1940 and expanded to the entire Java in 1951 ( Diratmaja \& Permadi, 2005). BPH explosion occurred in West Java and Central Java in 1960-1970 resulted in the destruction of 52,000 hectares of paddy crop. In the next period, 1976 - 1977, it attacked 1.5 million hectares of the crop with a yield loss of more than 2.3 million tons. In $2000-2005$, BPH attacked 20,000 hectares of rice planting area/year (Kartoharjono, 2011). Indonesia became one of BPH migration destination because it has the characteristics of topography and climate that supports the breeding so as to regenerate up to 12 generations per year. BPH has an ability to form a large enough population in a short time because of the rapid proliferation ability and the ability of adaptation to environmental changes (Marheni, 2004). The magnitude of population development on a stretch of BPH is caused by several factors: (1) biotypes, (2) the variety, (3) the cropping pattern, (4) insecticides, and (5) climate (Baehaki, 2011; Dharmasena et al., 2000; Susanti et al., 2010; Olanrewaju, 1998; Win et al., 2011). The importance of the use of GIS in agriculture is the provision of an early warning system against attacks BPH in rice (Susanti et al., 2010; Xiaofang et al., 2008; Kleinhenz et al., 2010; Nguyen et al., 2012). The virtue of this study compared with the results of previous studies is that early warning of endemic regions based on the region of connectivity possibilities.

\section{Previous Research}

Spatial autocorrelation is a method for exploration and spatial data analysis (ESDA). ESDA has been used to study modeling and simulation of various natural phenomena that occur in the real world. Models and simulations needed because not all natural phenomena can be visually identified the causes and effects. Features available in the ESDA for such purposes are: (1) visualization of the spatial distribution, (2) identification of the location of atypical or outliers, (3) the representation of spatial association patterns, and (4) identification hotspots, coldspot and spatial regime (Anselin, 1993a; Anselin 1993b; Anselin 1994; Anselin 1996). ESDA previous research method is the use of modeling and spatial patterns of connectivity among districts as BPH endemic areas in Central Java province of Indonesia. The spatial pattern of BPH endemic areas were identified based on the hotspot and coldspot resulting from the analysis using Moran 's I and Getis Ord (Prasetyo et al., 2012). In further research, Moran's and Getis Ord can be developed for modeling connectivity endemic areas as migration paths and BPH distribution in the expanse of rice fields in 124 districts in Central Java Province Indonesia ( Prasetyo et al., 2013).

\section{Theoretical Background}

Generally Getis Ord uses to determine: (1) hotspot, connectivity attribute data in neighboring regions will form a pattern of convergence, if the value of $Z>1.96$ and (2) coldspot, if the value of $Z<1.96$. Value $Z$ (Wuschke et al., 2013). The Function of Getis Ord Statistic according to Getis and Ord (1996 ) can be seen in the equation :

$$
G_{i}(d)=\frac{\sum_{j=1}^{m} w_{i j} X_{j}}{\sum_{j=1, j \neq i}^{m} x_{i}}
$$

and

$$
G_{i}^{*}=\frac{\sum_{j=1}^{m} w_{i j} X_{j}}{\sum_{j=1}^{m} X_{i}}
$$

The notation is an area identified by geo-referenced to $a=1,2, \ldots$ Each value associated with the variable value of research in the study area is represented by the notation. Notation is the spatial weight vector with values defined as the distance between regions. Triple Exponential Smoothing is used for processing data that is seasonal, formulated as the following, trend, seasonal and predicts according to Makridakis (1999) in Raharja et al., (2009):

$$
\begin{gathered}
b_{t}=g\left(S_{t}-S_{t-1}\right)+(1-g) b_{t-1} \\
I=b \cdot \frac{t X}{t S+(1-b) t-L+m} \\
F_{t}+m=\left(S_{t}+b_{t} m\right) I_{t}-L+m
\end{gathered}
$$

In which $b_{t}$ is value trend in the period, $S_{t}$ is prediction in period $\mathrm{t}, F_{t}+m$ is the prediction results for m, $m$ is Number of periods ahead to be forecast, $L$ is length of the season (number of seasons per year), $F_{t}+$ $m$ is prediction at time $\mathrm{t}$ and $\mathrm{m}$ periods season, and $I$ is seasonal adjustment. 


\section{The Research Method}

Stages of the study are: (1) the collection and preprocessing of the data resulted in the classification of data in the form of monthly, years and local classification these name is mangsa, 2) database development, (3) the create of the component class Exponential Smoothing, Weight Metrics, G and G * function, (4) development of the GIS applications, (5) information visualization in the form of graphs, maps and tables.

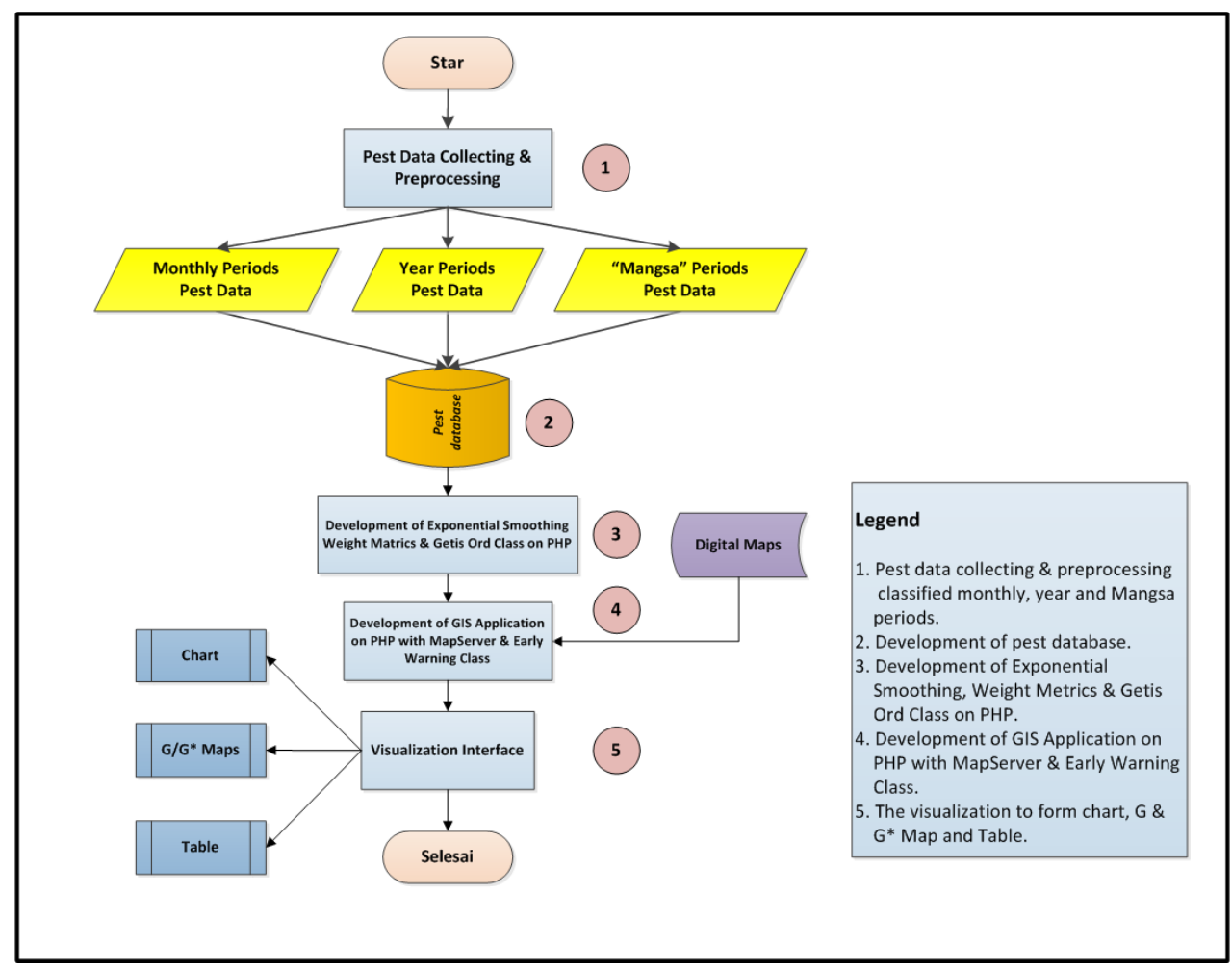

Figure 1. Stages of research

The study area covers 120 districts in Klaten, Sukoharjo, Sragen, Karanganyar, Wonogiri and Boyolali Central Java Province, Indonesia. The data used for the research is BPH Attack data derived from Laboratory Observations Pest and Disease (BBPOPT) Central Java Province, Indonesia. BPH Attack is a secondary data from surveillance of pest officers taken every two weeks for 10 years, between the years 2001-2010. Stages of research can be seen in Figure 1. Application of GIS was developed using the PHP programming language and Mapserver.

\section{The Result and Discussion}

Scientific contributions in this study is set of object classes in an application that consists of three elements : (1) Class Prediction Engine, (2) Class Getis Ord and (3) Class Early Detection. Class Prediction Engine retrieves data from a MySQL database. It displays information trends and predictions in the form of a table. Class Getis Ord retrieves data from a MySQL database, calculate the Weight Metrics to determine the spatial connectivity and show the calculation results in the form of thematic maps follow the rules in $G *$. Map displayed using MapServer MS4W in all types of web browsers. Class Early Detection generates an early warning when the value of $G *$ calculation results are above the threshold criteria value. Interpretation of value in the analysis of Getis Ord using indicators $Z(\mathrm{Gi})$. Interpretation of $Z(\mathrm{Gi})$ is $(-2.0<\mathrm{Z}(\mathrm{Gi})<2.0)$, the value of $(\mathrm{Z}(\mathrm{Gi})<-2.0)$ represent the distribution of data outliers and random, whereas $(Z(G i)>2.0)$ represent the distribution of data centralized (clusters). Architectural details of the main components of GIS applications constituent early warning $\mathrm{BPH}$ can be seen in Figure 2. 


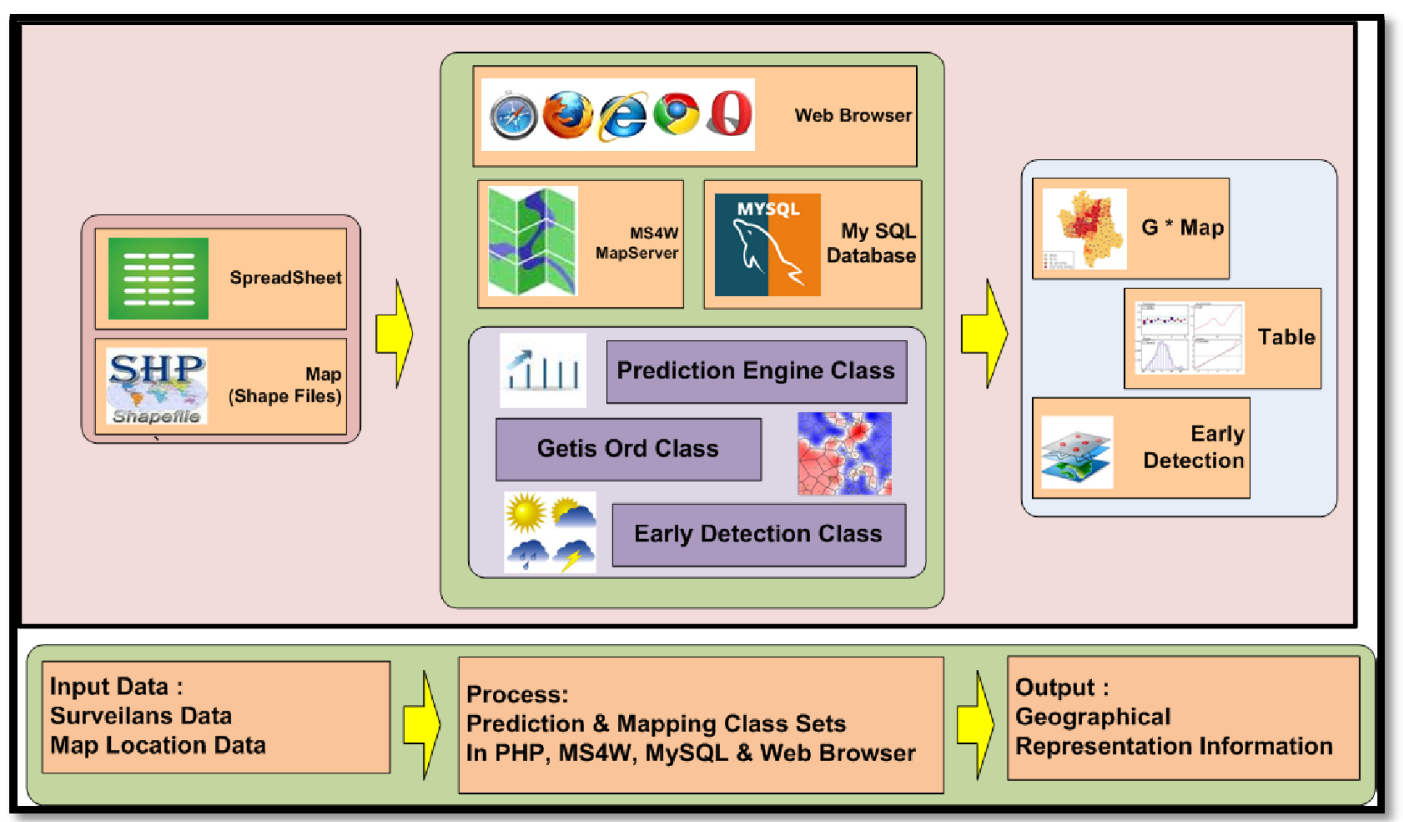

Figure 2. Architectural details of Early Warning BPH application

Stages of operation GIS Early Warning BPH application is determined by steps in the Class Getis Ord and Class Early Detection as in pesudocode Figure 3. Pesudocode class prediction engine and follow the steps in Figure 4, below.

\section{Step 0 Initialization data districts neighbor}

Phase I: generate patterns of weight matrix

Step 1 Take a list of neighbors among the data (bordering directly or indirectly) = n neighbors

Step 2 Repeat steps 2-3 until the weight matrix $a X$ b as many as $n$ for each $a$ and $b$, or $[n \mid a, b]$.

Step 3 Take the neighbor connectivity value, if bordering on the value of $W$ (Weight matrix) is 1 , otherwise is 0

Step 4 Normalized weight matrix, when dealing with itself then worth 1. Repeat steps 4-5 until normalization axb matrix formed

Step 5 IF $a=b$ THEN matrix $[a][b]=1$ (matrix normalization)

Phase II : generate $G$ * value

Step 6 Repeat steps 7-8 from 0 to a number of columns. From the matrix a $x b$

Step 7 Each value matrix is multiplied by the value of the pest over $[x]=\operatorname{top}[x]+($ matrix $[a][b] *$ value $B P H$ )

Step 8 Each OPT values of all neighbors summed Down $[x]=$ down $[x]+($ value BPH)

Step $9 G^{*}$ value $=$ top $[x] /$ down $[x]$

Figure 3. Pseudocode the Class Getis Ord and Class Early Detection 
Step 0 Initialize the actual data series over time.

Save the actual data rows in the array.

Initialize the value of smoothing (alpha), with a range of values between 0 and 1 .

Phase I : generate pattern prediction of the actual value

Step 1 Repeat steps 2-7 until the amount of data that has been entered is fulfilled .

Step 2 Process each data so from the value [ $i$ ] will generate predictions [ $j$ ] ( the actual value produces the predicted value).

Step 3 Repeat steps 4-7 until the actual data length is met.

Step 4 First, triple exponential smoothing is performed three times a smoothing, which is indicated by the command :

Step 5 Calculate 1 [ $i]=($ alpha $*$ value $)+((1-$ alpha $) * s 1[i-1])($ single smoothing $)$

Calculate $2[i]=($ alpha $* s 1[i])+((1-$ alpha $) * s 2[i-1])($ double smoothing $)$

Calculate $3[i]=($ alpha $* s 2[i])+((1-$ alpha $) * s 3[i-1]))($ triple smoothing $)$

Step 6 Calculate A value $[i]=(3 * s 1[i])-(3 * s 2[i])+\$ 3[i]$

Calculate $B$ value $[i]=$ alpha $/(2 *((1-$ alpha $) *(1-$ alpha $)))) *(((6(5 *$ alpha $)) *$ $s 1[i])-((10-(8 *$ alpha $)) * s 2[i])+((4-($ alpha $* 3)) * s 3[i]))$

Calculate Cvalue $[i]=(($ alpha $*$ alpha $) /(((1-$ alpha $) *(1-$ alpha $)))) *(s 1$ [i]-(2 $* s 2[i])+s 3[i])$

Step 7 Calculate $F$ value $[i]=A$ value $[i]+(i B[i] * 1)+(0.5 *(C$ value $[i] * 1 * 1))$

Phase II : generate predictive value $n$ periods

Step 8 Repeat steps 9-10 of the amount of data $(j)+1$.

Step 9 Load $A$ value $[j], B$ [j], $C$ value $[j]$.

Step 10 Calculate prediction $[j]=$ A value $[j]+(B$ value $[j] *$ period $)+(0.5 *(C$ value $[j] *$ period * period)).

Figure 4. Pseudocode class prediction engine Triple Exponential Smoothing

Visualization of geographic information system application results of this study broadly consists of three forms: (1) visualization of spatial connectivity endemic region (Figure 5), (2) visualization of early warning endemic areas (Figure 6), and (3) charts and predictions BPH attacks rain each study area (Figure 7). Application visualization system is done on Map server website and using PHP programming language. Incidence of endemic BPH connectivity between regions is marked with the same color, it means having the same value of $\mathrm{G}$ * as well. At the same color and the same value of $\mathrm{G} *$ can happen and does not necessarily affect the existence of spatial connectivity between these regions (Figure 5). The value of $\mathrm{G} *$ will be used as an early warning trigger endemic areas in accordance with the criteria above threshold values (Figure 6). 


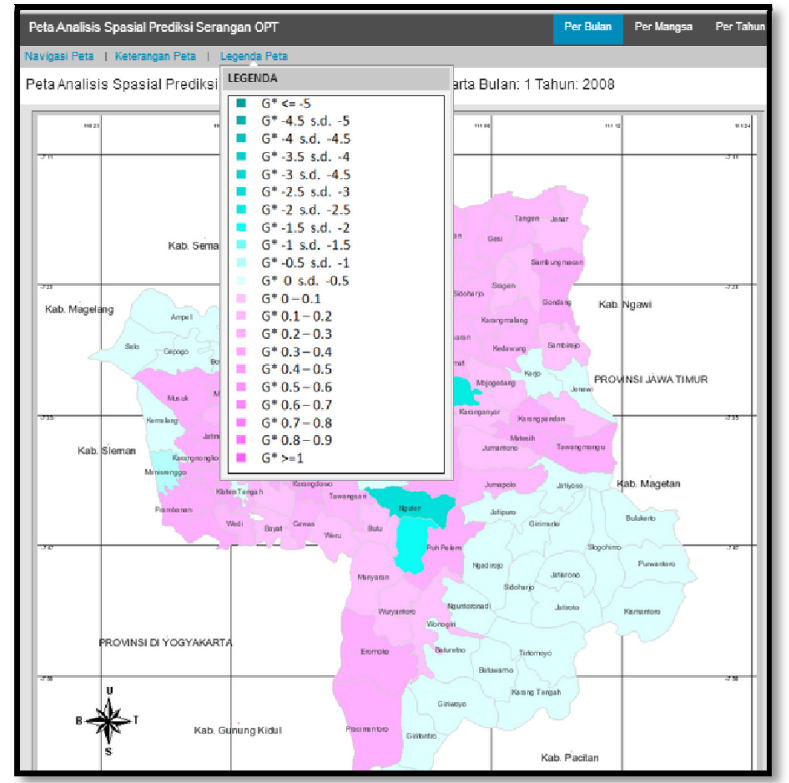

Figure 5. Visualization of spatial connectivity BPH endemic areas

In Figure 6 show Early Warning visualization models of each district and sub-district in the next period. Triple Exponential Smoothing method is used to determine the next period prediction. The method is used because it is very accurate in the short-term forecast.

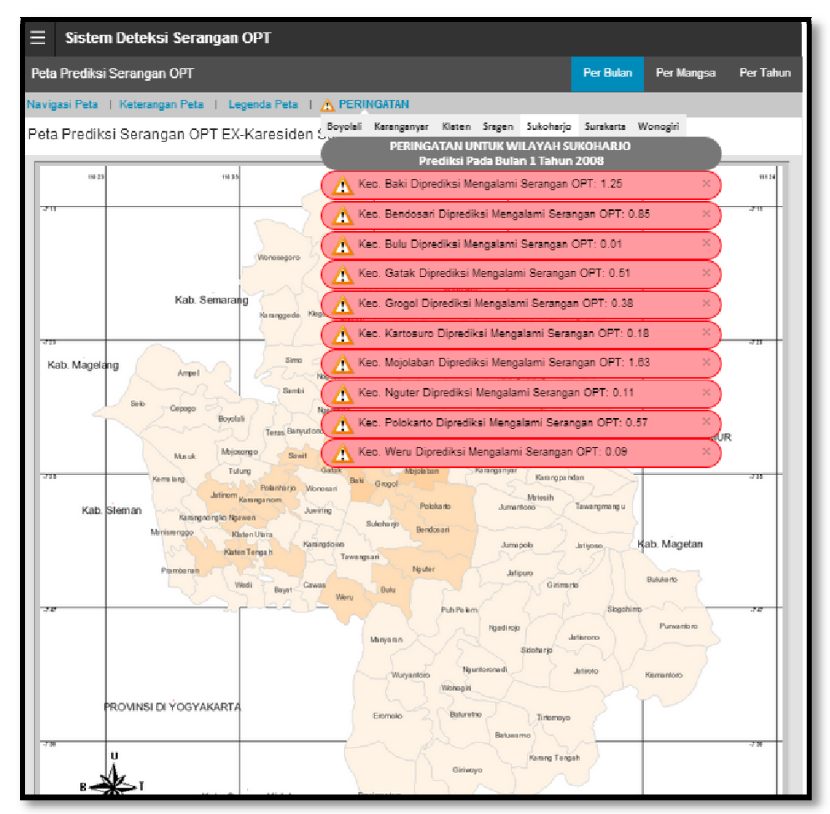

Figure 6. Visualization early warning BPH endemic areas

Visualized BPH results predicted in graphical form by comparing the actual data and the data predicted results will make user compare easily between the cycles and trends of BPH attack and rain both actual and seasonally (Figure 7.). 


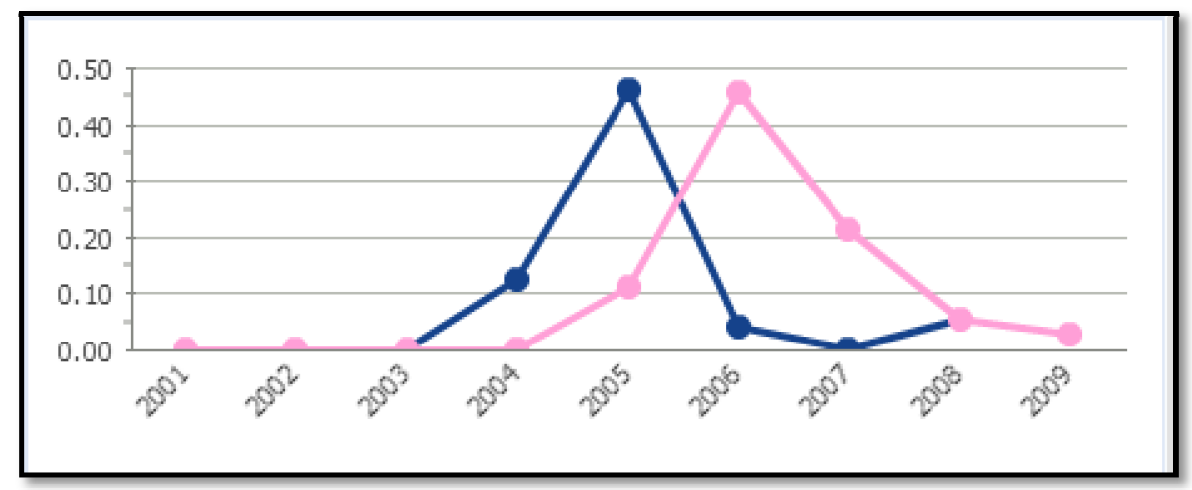

Figure 7. Visualization comparison of the actual data and the data predicted $\mathrm{BPH}$

\section{Conclusion and Future Work}

The result of this study show that the software components in this study; class prediction engine, class Getis Ord and class early detection function optimally generate predictive information, endemic regions information and early warning information on the next period. In future study, this three classes computational capabilities need to be improved in order to work faster by added optimization functions. Furthermore, it required classes that enable to analyze data shape files separate from the application.

\section{Acknowledgments}

This study is fully funded through Competitive Grant of The Directorate of Higher Education RI 2014 Contract No. 001/K6/KL/SP/Penelitian/2014. This research is in collaboration between the Simitro Research Group Satya Wacana Christian University, Department of Agriculture district of Boyolali and Karanganyar, Center for Plant Pest Forecasting Organisms (BPOPT) and Indonesian Agency for Meteorology, Climatology and Geophysics (BMKG).

\section{References}

Anselin, L., Dodson, R. F., \& Hudak, S. (1993). Linking GIS and Spatial Data Analysis in Practice. Geographical Systems, (1), 3-23.

Anselin L. (1993a). Exploratory Spatial Data Analysis and Geographic Information System, National Center for Geographic Information and Analysis University of California, Santa Barbara.

Anselin L. (1993b). Local Indicator of Spatial Analysis, National Center for Geographic Information and Analysis University of California, Santa Barbara.

Anselin L. (1994). Local Indicator of Spatial Analysis, Regional Research Institute West Virginia University, Gorgantown, WV.

Anselin L. (1996). The Moran Scatterplot as an ESDA Tool to Asses Local Instability in Spatial Association. Spatial Analytical Perspective in GIS, Taylor and Francis, London, 1996.

Anselin, L. (1993). The Moran Scatterplot as an ESDA Tool to Asses Local Instability in Spatial Association, GISDATA. Specialist Meeting, on GIS and Spatial Analysis, The Neterlands.

Anselin, L. (1993a). Exploratory Spatial Data Analysis and Geographic Information System. National Center for Geographic Information and Analysis University of California, Santa Barbara.

Anselin, L. (1993b). Local Indicator of Spatial Analysis, National Center for Geographic Information and Analysis University of California, Santa Barbara

Anselin, L. (1994). Local Indicator of Spatial Analysis, Regional Research InstituteWest Virginia University, Morgantown, WV.

Anselin, L. (1995). Local Indicator of Spatial Association. Geographical Analysis, 27(2), 93-115. http://dx.doi.org/10.1111/j.1538-4632.1995.tb00338.x

Anselin, L. (1996). The Moran Scatterplot as an ESDA Tool to Asses Local Instability in Spatial Association (pp. 111-125). Spatial Analytical Perspective in GIS, Taylor and Francis, London. 
Anselin, L. (1998). GIS Research Infrastructure for Spatial Analysis of Real Estate Markets. Journal of Housing Research, 9(1), 113-133.

Baehaki, (2011). Normalisasi dan Pengendalian Dini Hama Wereng Cokelat Pengaman Produksi Padi Nasional, Sinar tani, Edisi 20-26 Juli 2011 No.3415 Tahun XLI, Badan Litbang Pertanian (In Indonesia Language).

Baehaki. (2011). Strategi Fundamental Pengendalian Hama Wereng Batang Cokelat Dalam Pengamanan Produksi Padi Nasional. Pengembangan Inovasi Pertanian, 4(1), $63-75$ (In Indonesia Language).

Bottrell, D. G., \& Schoenly, K. G. (2012), Resurrecting the ghost of green revolutions past: The brown planthopper as a recurring threat to high-yielding rice production in tropical Asia, Department of Entomology, University of Maryland, College Park, Maryland 20742, USA. Journal of Asia-Pacific Entomology, 15, 122-140. http://dx.doi.org/10.1016/j.aspen.2011.09.004

Chen, J., \& Jiang, J. (2010). Analysis of Spatial Autocorrelation for Point Objects Based on Line Buffer, School of Remote Sensing Information Engineering, Wuhan University, Wuhan Hubey, China.

Chowell, G., Ariel, L. R., Stephen, D. S. MS., \& Hyman, J. M. (2006). Identification of case clustersand counties with high infective connectivity in the 2001 epidemic of foot-and-mouth, disease in Uruguay. AJVR, 67(1), 102-113. http://dx.doi.org/10.2460/ajvr.67.1.102

Dharmasena, C. M. D., Ranaweer, R. M., Banda, \& Fernando, M. HJ. R. (2000). Effect of climatic factors and agronomic practices on brown planthopper (Nilaparvata lugens) outbreak in the Anuradhapura District, Sri Lanka. Tropical Agriculture Research and Extention, 3(2), 133-136.

Diratmaja, I. A., \& Permadi, K. (2005). Attack And Population Brown Planthopper ( Nilaparoata lzgens Stal.) At Rice In Cirebon, Indramayu And Karawang. J. Agrivigor, 5(1), 55-63.

Ji, W., \& Cui, J., (2011). Application of Geographical Information System (GIS) in Agricultural Land classification and Grading, 2011 International Conference on Agricultural and Natural Resources. Engineering Advances in Biomedical Engineering, 3(5), 201-205.

Johnson, L. B. (1990). Analyzing spatial and temporal phenomena using geographical information systems, A Review of Ecological Applications. Landscape Ecology, 4(1), 31-43. http://dx.doi.org/10.1007/BF02573949

Kartoharjono, A. (2011). Penggunaan Musuh Alami Sebagai Komponen Pengendalian Hama Padi Berbasis Ekologi. Pengembangan Inovasi Pertanian, 4(1), 29-46 (In Indonesia Language).

Kleinhenz, B., \& Zeuner, T., (2010). Use of Geographic Information Systems (GIS) in Crop Protection Warning Service, Twelfth Euro Blight workshop Arras (France), 3-6 May 2010, PPO-Special Report 14, 59 - 66.

Langford, H. L. (1999). Multilevel Modelling of The Geographical Distributions of Disease, University of EastAnglia, Norwich, University College London and Institute of Education London, UK. Appl. Statist, 48(2), 253-268. http://dx.doi.org/10.1111/1467-9876.00153

Marheni. (2004). Kemampuan Beberapa Predator pada Pengendalian Wereng Batang Cokelat (Nilaparvata lugens Stal.). Jurnal Natur Indonesia, 6(2), 84-86 (In Indonesia Language).

Nguyen, V. G. N., Drogoul, A., \& Huynh, H. X. (2012). Toward an Agent-based Multi-scale Recommendation System for Brown Plant Hopper Control, Institut de recherche pour le développement Bondy, France.

Olanrewaju, R. M. (1998). Effect of Climate on Pests Outbreak On The Sub-Humid Region of Nigeria: A Case Study of Kabba , Kogi State. International Journal of Urban and Regional Affairs, 2(2), 19-23.

Prasetyo, S. Y. J. P., Subanar, Winarko, E., \& Daryono, B. S. (2012). Endemic Outbreaks of Brown Planthopper (Nilaparvata lugens Stal.) in Indonesia using Exploratory Spatial Data Analysis, IJCSI International Journal of Computer Science Issues, Vol. 9, Issue 5, No 1, September 2012, ISSN (Online): 1694-0814.

Prasetyo, S. Y. J. P., Subanar, Winarko, E., \& Daryono, B. S. (2013). The Prediction of Population Dynamics Based on The Spatial Distribution Pattern of Brown Planthoppers (Nilaparvata lugen,Stal.) using Exponential Smoothing - Local Spatial Statistics. Journal of Agricultural Science, 5(5). Canadian Center of Science and Education.

Raharja, A., Wiwik, A., \& Retno, A. V. (2009). Penerapan Metode Exponential Smoothing untuk Peramalan Penggunaan Waktu Telepon Di PT. Telkom Divre 2 Surabaya, Sistem Informasi, Fakultas Teknologi Informasi, Institut Teknologi Sepuluh November, SsISFO-Jurnal Sistem Informasi (In Indonesia Language).

Rudnick, D. A., Ryan, S. J., Beier, P., Cushman, S. A., Dieffenbach, F., Epps, C. W., ... Trombulak, S. C. (2012). 
The Role of Landscape Connectivity in Planning and Implementing Conservation and Restoration Priorities, The Ecological Society of America.XVI.

Seino, H., Shiotsuki, Y., Oya, S., \& Hirai, Y. (1987). Prediction of Long Distance Migration of Rice Planthoppers to Northern Kyushu Considering Low-Level Jet Stream, Kyushu National Agricultural Experiment Station, Chikugo, Fukuoka 833, Japan.

Susanti, E. F. R., June, T., \& Amien, L. I. (2010). Utilization of Climate Information for Development of Early Warning System for Brownplanthoppers Attack on Rice, Indonesian Hydrology and Agroclimate Research Institute, Jalan Tentara Pelajar No. 2, Bogor 16111, West Java. Indonesian Journal of Agriculture, 3(1), 17-25.

Susanti, E. F. R., June, T., \& Amien, L. I. (2010). Utilization of Climate Information for Development of Early Warning System for Brownplanthoppers Attack on Rice, Indonesian Hydrology and Agroclimate Research Institute, Jalan Tentara Pelajar No. 2, Bogor 16111, West Java. Indonesian Journal of Agriculture, 3(1), 17-25.

Taupier, R., \&Willis, C. (1994). Geographic Information Systems and Applied Economics:An Initial Discussion of Potential Applications and Contributions, Office of Geographic Information and Analysis, Blaisdell House, Box 30320, University of Massachusetts, Amherst, MA.

Theobald., D. M. (2001). Topology revisited: representing spatial relations, Natural Resource Ecology Laboratory, Colorado State University, Fort Collins, CO 80523-1499, USA. International Journal of Geographical Information Science, 15(8), 689-705. http://dx.doi.org/10.1080/13658810110074519

Wada, T, Ito, K., Takahashi, A., \& Tang, J. (2008). Starvation tolerance of macropter brown planthopper, Nilaparvata lugens, from temperate, subtropical, and tropical populations in East and South-East Asia. Entomologia Experimentalis et Applicata, 130, 73-80. http://dx.doi.org/10.1111/j.1570-7458.2008.00796.x

Wang, C., Li, D., Hu, Y., Wu, X., \& Qi, Y. (2009). Research of spatio-temporal analysis of agricultural pest, LIESMARS, Wuhan University, Wuhan, Hubei, China 430079, International Symposium on Spatial Analysis, Spatial-Temporal Data Modeling, and Data Mining. http://dx.doi.org/10.1117/12.838413

Win, S. S., Muhamad, R., Ahmad, Z. A. M., \& Adam, N. A. (2011). Population Fluctuations of Brown Plant Hopper Nilaparvata lugens Stal. And White Backed Plant Hopper Sogatella furcifera Horvath on Rice. Journal of Entomology, 8, 183-190. http://dx.doi.org/10.3923/je.2011.183.190

Wuschke, K., Clare, J., \& Garis, L. (2013). Temporal and geographic clustering of residential structure fires: A theoretical platform for targeted fire prevention. Fire Safety Journal, (62) A, 3-12. http://dx.doi.org/10.1016/j.firesaf.2013.07.003

Xiaofang, W., Changwei, W., Zhiyong, X., \& Yueming, H. (2008). Application of GIS technology in monitoring and warning system for crop diseases and insect pests. Geoinformatics and Joint Conference on GIS and Built Environment: Monitoring and Assessment of Natural Resources and Environments, Proc. of SPIE 7145, 714516. http://dx.doi.org/10.1117/12.813020

\section{Copyrights}

Copyright for this article is retained by the author(s), with first publication rights granted to the journal.

This is an open-access article distributed under the terms and conditions of the Creative Commons Attribution license (http://creativecommons.org/licenses/by/3.0/). 